\title{
Korelasi Qiyafah dan Genetika Dalam Menetapkan Nasab Perspektif Imam Syafi'i
}

\author{
Drs. Abdul Hakim Siregar, MA \\ Dosen Program Studi Pendidikan Biologi FKIP Universitas Islam Sumatera Utara \\ abdulhakims@fkip.uisu.ac.id
}

\begin{abstract}
ABSTRAK
Bahwa Qiyafah merupakan istilah metoda yang dipakai untuk mengenali jejak seseorang dalam menetukan nasab berdaarkan ciri-ciri dan kemiripan. Sedangkan qa if, adalah orang yang mempunyai keahlian khusus melihat orang lain dalam menghubungkan, menetukan nasab berdasarkan tanda-tanda dan kemiripan antara pihak yang diteliti. Menurut asy-Syafi ` $i$, jasa qa if dalam menetapkan nasab seseorang dapat diterima sebagai ketetapan hukum. Oleh sebab itu, jika ditemukan persengketaan nasab dimana tidak ada bukti lain atau para pihak sama-sama memiliki bukti yang kuat, maka persoalan itu diselesaikan dengan penelitian qa if. Dalam mendukung pendapatnya, mazhab asy-Syafi i beralasan dengan hadits Nabi Muhammad saw.dan atsar para sahabatnya. Oleh sebab itu praktik qiyafah diyakini memiliki justifikasi syariah. Genetika adalah salah satu cabang dari ilmu biologi yang membahas tentang sifat keturunan yang diwariskan serta variasi yang mungkin timbul di dalamnya. Praktik qiyafah maupun genetika sama-sama bertujuan untuk meneliti sifat keturunan yang diturunkan secara turun temurun. Dilihat dari kesamaan fungsi dan tujuan ini, maka qiyafah memiliki relevansi dengan ilmu genetika dalam menetapkan nasab seseorang. Dan ketetapan ilmu modern yang berdasarkan hasil tes DNA sama kekuatan hukumnya dengan ketetapan qiyafah perspektik imam Syafi’ i.
\end{abstract}

Kata Kunci : Qiyafah, Genetika, Nasab Perspektif Imam Syafi'i

\begin{abstract}
That Qiyafah is the term method used to identify the traces of a person in determining nasab based on characteristics and similarities. Whereas qa if, is a person who has special expertise to see other people in connecting, determine nasab based on signs and similarities between the parties studied. According to AshSyafi'i, qa if services in determining one's language can be accepted as legal provisions. Therefore, if a nasab dispute is found where there is no other evidence or the parties both have strong evidence, then the problem is solved by qa if research. In supporting his opinion, the school of Ash-Syafi'i reasoned with the hadith of the Prophet Muhammad and his companions. Therefore the practice of qiyafah is believed to have sharia justification. Genetics is a branch of biology that discusses inherited traits and variations that may arise in it. The practice of qiyafah and genetics are both aimed at examining the nature of the offspring which is passed down from generation to generation. Judging from the similarity of functions and goals, then qiyafah has relevance to the science of genetics in determining one's nasab. And the determination of modern science which is based on the results of DNA tests is as powerful as the law with the provisions of qiyafah the perspective of the Imam Shafi'i
\end{abstract}

Keywords : Qiyafah, Genetics, Nasab Perspective of Imam Shafi'i 
Hakim Siregar A : Korelasi Qifayah dan Genetika Dalam Menetapkan Nasab Perspektif Imam Syafi'i

\section{PENDAHULUAN \\ 1. Latar Belakang}

Allah telah menurunkan tuntunan dan pedoman hidup kepada manusia dengan sempurna. Tuntunan itu adalah agama Islam yang dibawa oleh Nabi Muhammad Rasulullah saw. Secara sederhana, ajaran Islam dapat dikelompokkan ke dalam bidang ibadah dan muamalah. Pembagian ini bukanlah dikotomisasi yang permanen dalam Islam, namun hanya sebagai kategorisasi untuk memudahkan memahami karakter dominan dari ajaran Islam. Dalam khazanah karya-karya intlektual muslim, kajian tentang hukum muamalah termasuk kajian yang selalu berkembang yang banyak dikaji, dan ulasan-ulasan tersebut telah berlangsung secara kreatif, evaluatif dan berkesinambungan sejak priode awal hingga era millenium ini. Berbicara seputar hukum Islam akan dihadapkan kepada suatu bahasan yang sangat luas dan kompleks, sebab ia mempunyai sejarah, lingkungan dan sumbersumber hukum dan mazhabnya. Keseluruhan aspek ini menunjukkan bahwa wacana tentang hukum Islam sangat kaya dan luas sekali. Kajian ini berusaha megangkat suatu hasil pemikiran mazhab Syafi i di seputar pemikiran penetapan nasab berdasarkan metoda qiyafah. Nasab adalah penetapan hubungan darah antara seseorang dengan orang lainnya yang diakui oleh syara` dan dengan penasaban tersebut akan menghasilkan akibat hukum seperti kewarisan dan kewalian. Qiyafah merupakan metoda yang dipakai untuk perbuatan qa if. Qa if adalah : orang yang mengikuti jejak dan mengenali yang punya jejak. Dan orang yang dapat mengenali nasab seseorang melului firasatnya dan atau dengan penelitiannya terhadap anggota badan si anak. ${ }^{1}$ Dari keterangan ini dapat dipahami bahwa qa if adalah orang yang mempunyai keahlian khusus yang diberikan Allah swt terhadapnya dalam memerhatikan, menghubungkan dan menetapkan nasab seseorang dengan orang lainnya. Hal ini dapat diketahui berdasarkan tanda-tanda dan kemiripan antara seseorang itu dengan anaknya.atau orang tuanya. Dengan demikian qiyafah berarti metoda seseorang yang melakukan penelitian serta pemeriksaan secara cermat berdasarkan kemiripan atau pada ciri-ciri lahiriyah didukung dengan keahlian yang diberikan Allah terhadapnya. Peraktik penelitian atas kemiripan atau asal-usul keturunan (nasab) seperti ini telah dikembangkan ilmu pengetahuan modern dan diakui sebagai suatu bentuk sains yang disebut dengan ilmu genetika. Ilmu genetika disebut juga sebagai ilmu keturunan. Dalam ilmu tersebut dikembangkan suatu penelitian terhadap berbagai sifat keturunan (hereditas) itu diturunkan atau diwariskan kepada anak cucu, serta variasi yang mungkin timbul di dalamnya.

\section{Perumusan Masalah}

Kata "Syafii" di nisbahkan kepada nama kakeknya yang ke tiga, yaitu Syafi’i bin as-Sa`ib. Ayahnya bernama Idris bin Abbas bin Ustman bin Syafi i bin as-Sa 'ib bin Abid bin Abdul Yaziid bin Hasyim bin Abdul Mutalib bin Abdul Manaf. Sedang dari ibunya bernama Fatimah binti Abdullah bin al-Hasan bin Husein bi Ali bin Abi Thalib. Dari garis keturunan ayahnya, Imam Syafii bersatu dengan keturunan Rasulullah Muhammad saw.pada Abdul Manaf, kakek Rasulullah Muhammad saw. yang ke tiga. Sedangkan dari pihak ibunya, ia adalah cicit dari Ali bin Abi Thalib, bangsa Quraisy. Imam Syafii di tinggal mati ayahnya saat ia masih kecil, ia ditinggalkan menjadi anak yatim, dan ia diasuh ibu kandungnya, dan dibawa ibunya ke Mekkah tanah kampung ibunya dalam kehidupan yang pas pasan. Imam Syafii berkat asuhan ibunya usia 9 tahun sudah hafal Alqur an, dan pada usia 10 tahun ia sudah dapat membaca seluruh (tammat) kitab Al-Muwatta`, karangan Imam Malik. Tidak cukup begitu saja, Imam Syafii berangkat ke Madinah untuk belajar 
Hakim Siregar A : Korelasi Qifayah dan Genetika Dalam Menetapkan Nasab Perspektif Imam Syafi'i

fikih langsung kepada Imam Malik (pengarang kitab al-Muwatta'). Setelah beberapa kemudian, ia meninggalkan Madinah menuju Irak untuk belajar dan memperdalam ilmunya, di Madinah ia bertemu dengan Imam Abu Yusuf dan Imam Muhammad bin Hasan, keduanya adalah sahabat akrab Imam Abu Hanafiah (Imam Hanafi). Setelah dua tahun di Irak, ia perdi ke Persia, Hirah, Palestina dan Ramalah dekat Baitul Maqdis. Kamudian ia pindah ke Yaman atas undangan pemerintaha Yaman menjadi wali negeri Yaman, dan diangkat lagi menjadi penasihat pemerintah Yaman membidangi masalah hukum. Di negeri Yaman ini, beliau menikahi seorang putri bangsawan bernama "Siti Hamidah binti Nafi ", cicit Uman bin Affan ra, dan dikurniai tiga orang anak; Abdullah bin Syafii, Fatimah binti Syafii dan Zainab binti Syafii. Setelah beberapa tahun berada di negri Yaman, Imam Syafii kembali lagi ke Bagdad, dan pindah lagi ke Mesir atas panggilan wali negeri (Abbas bin Musa). Di Mesir ia mengajar di Masjid Amar bin `As. Dan di Mesir inilah ia menyusun tulisan-tulisannya, buku-bukunya, alur pikirnya dan hasil ijtihadnya selama tinggal di Mesir, dan inilah kemudian ia dikenal dengan pendapatnya "al-Qawl alJadid/Pendapat baru".

\section{Tujuan Penelitian}

Mengenai hubungan kenasaban, Allah telah menyebut dalam QS.al-Furqan ayat, 52, bermakna : "Dan Allah yang menciptakan manusia dari air (maain), Kemudian Ia jadikan manusia itu punya keturunan (nasab) dan pertalian (musaharah). Allah adalah Tuhanmu Yang Maha Kuasa.”.

1. Cara penetapan nasab.

a. Sebab penetapan nasab.

Seseorang akan dinasabkan kepada ibunya dalam segala saat wiladah (kelahiran), yang melalui suatu perkawinan (pesetubuhan) yang sah sesuai dengan legitimasi syara dan atau mungkin tidak Sedangkan bagi seseorang ayah tidak ditetapkan kenasabannya kecuali dengan pernikahan yang sah, perkawinan yang fasid dan perkawinan yang syubhat.

a.1. Perkawinan yang sah, merupakan kesepakatan para ulama bahwa anak yang lahir dari perkawinan yang sah dinasabkan kepada kedua orang tuanya. Dalam hal ini dipersyaratkan hal-hal sebagai berikut.

>seorang suami dimungkinkan dapat menghamili istrinya menurut kebiasaan, yakni suami itu telah dan harus dewasa. Persyatan ini merupakan pendapat mazhab Syafi i dam Hanafi. Berdasarkan perinsip mereka ini, maka konsekwensinya, bila lahir anak tidak dapat dinasabkan kepada suami yang belum dewasa manakala istrinya hamil.

>Seorang anak dilahirkan ibunya minimal enam bulan setelah masa akad nikah. Demikian fikih Hanafi. Sedangkan mayoritas ulama, termasuk di dalamnya Imam Syafi i, terhitung sejak terjadinya wati (persetubuhan) dalam perkawinan tersebut. Kosekwensinya, bila lahir anak dari ibunya kurang dari masa minimal kelahiran, maka tidak dapat ditetapkan anak tersebut bagi uaminya.

a.2.Perkawian Fasid. Perkawinan fasid ini dapat menghubungkan kenasaban. Namun diperlukan tiga hal penting, yaitu:

>Adanya kemungkinan dalam perkawinan ini bahwa suami dapat menghamili wanita yang dinikahinya, seperti ia sudah dewasa.

$>$ Adanya indikasi terjadinya dukhul (senggama) di antara laki-laki dan wanita.

$>$ Wanita tersebut melahirkan anak setelah berlalu masa enam bulan atau lebih.

Apabila terpenuhi persyaratan yang telah disebutkan, maka laki-laki tersebut tidak dapat mengingkari nasab kecuali dengan melakukan li`an. Demikian menurut pendapat Syafi’i Sedangkan menurut mazhab Hanafi lakai-laki tersebut tidak tidak 
Hakim Siregar A : Korelasi Qifayah dan Genetika Dalam Menetapkan Nasab Perspektif Imam Syafi'i

dapat mengngkari kenasaban anaknya sekalipun dengan li`an, sebab li`an hanya dapat dilakukan dalam perkawinan yang sah.

b. Tata-cara penetapan nasab.

Cara penetapan nasab seseorang dengan orang lainnya dapat terjadi dengan tiga kemungkinan, yaitu :

b.1. Dengan malakukan perkawinan yang sah atau dengan perkawinan yang fasid,

b.2. Dengan cara pengakuan dan pendakwaan nasab. Pengakuan nasab terbagi kepada dua macam, yaitu; pengakuan yang dinisbahkan untuk dirinyaa sendiiri dan pengakuan yang dinisbahkan kepada selain dirinya. Adanya pengakuan nasab untuk dinisbahkan kepada dirinya sendiri seperti pengakuan seseoranng sebagai seorang ayah terhadap seorang anak, atau pengakuan seseorang sebagai anak dari seorang ayah. Contoh : aeorang ayah berkata "ini adalah anakku" dan atau "ini adalah ayahku"

b.3. Dengan cara mengemukakan bukti (bayyinah).

Cara yang ketiga ini untuk menetapkan nasab seseorang ialah dengan mengemukakan bukti (bayyinah). Pengajuan bukti tersebut lebih kuat daripada pengajua ikrar. Berdasarkan rangkuman ini, maka dirumuskan bahwa nasab merupakan hubungan darah antara seseorang dengan orang lainnya, .

2. Urgensi nasab dalam Islam..

Kajian tentang nasab menempati posisi yang penting dalam ajaran Islam. Sebab ia terkait dengan masalah-masalah yang krusial. Contoh; di dalam kewarisan, pengetahuan tentang nasab merupakan suatu keniscayaan. Seseorang tidak akan bisa membagi harta warisannya seseuai dengan syara' tanpa mengetahui hubungan kenasaban diantara pihak-pihak yang saling mewarisi tersebut.Hal yang sama tentang suatu pernikahan, akan batal suatu pernikahan yang manakala suatu istri ada hubungan sedarah. Demikian juga tentang masalah keturunan, seseorang baru bisa dikatakan sebagai anak atau sebagai ayah apabila ada hubungan nasab antara mereka yang dilegetimasi Syara`. Sejalan dengan hal itu, masalah nasab itu juga terkait dengan persoalan perwalian di dalam pernikahan

\section{Manfaat Penelitian}

1. Pengertian qiyafah.

Jika diterjemahkan kedalam bahasa Indonesia, maka qiyafah, secara etimologi bermakna: "keahlian seseorang dalam dalam mengenali jejak orang lain" Sedangkan orang yang ahli dalam hal ini disebut dengan qa if. Jamak dari qa if disebut qaafah. Orang yang melakukan metoda qiyafah dikatakan juga denga qafah. Untuk melihat dasar pembentukan kata qafah, dapat dilihat dalam tasrif berikut ini yaitu; qafa-yaqufu-qaufan-qiyafatanqaaifan, artinya keahlian/profesional. Menurut Ar-Ramli, dalam bukunya Nihayah alMuhtaj, mengatakan bahwa secara etimologi, qiyafah ialah metoda penelitian terhadap jejak seseorang berdasarkan kemirifan/kesamaan". Menurut Muhammad Khatib alSyarbaini, secara etimologi, qiyafah itu ialah; "keahlian seseorang dalam meneliti jejak orarng tertentu". Secara terminologi makna qiyafah ialah; "Suatu metoda yang dilakukan seseorang untuk mendapatkan bukti hubungan kenasaban seseorang dengan orang lain berdasarkan kemiripan/kesamaanAr-Ramli, juga memberikan pendapatnya bahwa secara terminologi makna qiyafah itu adalah; "Seseorang yang dapat menghubungkan kenasaban orang lain ketika ada kesamaran, berdasarkan keahlian yang diberikan Allah kepadanya . Menurut Az-Zarkasi al-Ansari al-Syafi'iyah dalam kitabnya "Fath al- Wahhab, secara terminologi mendefinisikan qaif, ialah seseorang yang berkemampuan dapat menghubungkan nasab/keturunan orang lain ketika ada kesamaran. Kemampuan tersebut berdasarkan keahlian yang dianugrahkan Allah kepada seseorang merupakan kelebihan. Berdasarkan deskripsi tersebut di atas, maka dapat dipahami bahwa qa if adalah seseorang yang memiliki kemampuan, keahlian khusus (profesionalitas) yang dianugrahkan Allah 
Hakim Siregar A : Korelasi Qifayah dan Genetika Dalam Menetapkan Nasab Perspektif Imam Syafi'i

kepadanya dapat melihat, meneliti unyuk menghubungkan dan menetapkan nasab seseorang dengan orang lain dan diyakini kebenarannya. Hal ini ia ketahui berdasarkan tanda-tanda kemiripan/ kesamaan yang ada pada orang tersebut. Seperti hubungan antara anak dengan orang tuanya Dengan demikian qiyafah berarti suatu metoda untuk bertindak melakukan penelitian dan pemeriksaan berdasarkan keahlian seseorang melihat kesamaan, kemiripan tanda-tanda yang dimiliki mereka.

2.Sejarah dan dasar qiyafah dalam Islam .

Memang tidak ditemukan secara jelas dalam alquran yang menerangkan tentang eksistensi qiyafah sebagai penetapan nasab. Bahkan, kata qiyafah itu sendiripun tidak ada disinggung dalam alquran, namun masalah kenasaban atau keturunan dalam kehidupan manusia sejak dahulu terjadi, yaitu ketidak tahuan seorang anak siapa ayah kandungnya, atau seorang ayah ragu akan anaknya, dst. Maka dalam hal ini memerlukan solusi. Walaupun saat itu perkembangan ilmu penetahuan tidak atau belum sepesat kekinian, tetapi Allah memberikan keistimewaan bagi manusia memiliki keahlian khusus dalam menetapkan nasab, turunan seseorang berdasarkan penelitian dari sudut kemiripan yang dimiliki mereka.. Dan hal ini dapat diakui dan dipercaya masyarakat. Sehingga bagi mereka yang ragu akan anaknya menjadi yakin, demikian juga bagi mereka yang tidak mengetahui nasabnya sebelumnya menjadi tahu. Dasar hukum qiyafah dalam Islam adalah sunnah Rasulullah Muhammad saw. dan diketahui bahwa sunnah atau hadits Rasulullah Muhammad saw. merupakan dasae hukum Islam setelah Alquran. Maka prihal qiyafah ini dapat dilihat dan disimak dalam salah satu hadits Rasulullah Muhammad saw. yang diriwayatkan A isyah (istri Rasulullah saw) yang dikutip dalam kitab Al-Umm, (bermakna): Dari A isyah ra. Ia berkata; Telah datang kepadaku Rasulullah saw. dengan wajah yang penuh gembira, kemudian ia bersabda; apakah engkau belum mengetahui bahwa Mujazziz al-Mudliji telah datang kepadaku, dan ia melihat Usamah bin Zaid yang sama-sama memakai kerudung di atas kepalanya tetapi tampak telapak kakinya, lalu setelah itu si Muzazziz berkata: Ini merupakan telapak kaki sebagiannya dari sebagai lainnya. Mujazziz al-Mudliji, sebagaimana yang dikemukakan oleh Muhammad Khatib Syarbaini, adalah merupaka seorangqa if tang terkenal keahliannya dikalangan orangorang Arab. . Ia selalu dipanggil untuk menyelesaikan masalah bila ada perdebatan atau ada kesamaran, keraguan dalam masalah nasab atau keturunan seseorang dan memerlukan penyelesaian, maka penetapan yang diberikannya dapat diterima masyarakat, dan ini merupakan keahlian khususnya.

\section{GAMBARAN TENTANG PENELITIAN}

Genetika perlu dipelajari agar seseorang dapat mengetahui sifat-sifat keturunan manusia serta makhluk hidup lainnya yang berada dilingkungannya. Manusia tidak dapat hidup sendiri dan terisolir dari makhluk lain, sesuai dengan sifatnya makhluk sosial ia senantiasa berhajat kepada manusia dan makhluk lainnya. Oleh karena itu sangat perlu diketahui siaftsifat turun menurun pada manusia, pada tumbuhan dan hewan untuk berbagai macam rekayasa genetika. Charles Darwin, menyimpulkan bahwa keturunan yang berada dari perkawinan organisme yang tidak mempunyai hubungan keluarga (out breeding) lebih kuat dibanding keturunan hasil perkawinan antara organisma yang mempunyai hubungan keluarga (inbreeding). Meniere, seorang ahli penyakit syaraf dari Perancis, pada tahun 1856, menunjukkan bahwapada manusia, penyakit bisu, tuli lebih banyak terdapat pada anak-anak yang berasal dari perkawinan keluarga (inbreeding). Dengan pengetahuan ini, maka manusia dapat menghindarkan kemungkinan kecacatan itu dengan tidak melakukan perkawinan keluarga. Johannes adalah orang yang pertama kali menjelaskan perbedaan antara pengertian genotipe, yang berarti konstitusi genetika, dengan pengertian fenotipe, 
Hakim Siregar A : Korelasi Qifayah dan Genetika Dalam Menetapkan Nasab Perspektif Imam Syafi'i

yang berarti sifat-sifat individu, merupakan hasil intraksi antara genotipe dengan lingkungan. Genotipe pada dasarnya adalah ciri-ciri yang telah melekat pada individu, tetapi konstan sepanjang hidup dan boleh dikatakan tidak berubah karena pengaruh lingkungan. Sementara itu fenotipe umumnya berubah selama kehidupan individu dengan arah perubahan sebagai fungsi pengaruh lingkungan yang dialami individu. Alam kaitan genotipe dan fenotipe ini, suatu genotipe dapat menghasilkan berbagai macam fenotipe tergantung pada pengaruh lingkungan. Sebaliknya suatu fenotipe mungkin saja dihasilkan oleh berbagai macam genotipe tergantung pada lingkungan. Pada manusia perbedaan antara pengaruh eugenik alamiah dan [emeliharaan dijelaskan petama kali pada tahun 1875 oleh Sir Perancis Galton. Hal ini berarti pengetahuan terhadap sifat-sifat keturunan semakin bermakna untuk kebutuhan kedokteran. Dalam pada itu, Galton memiliki perhatian tentang perbaikan keturunan pada manusia dengan cara perkawinan selektif, dan untuk ini diajukannyalah istilah eugenik (program memproduksi selektif) Ketika ditanya ia cukup berelasan bahwa tujuan yang diinginkan oleh ahli genetika manusia tentunya adalah perbeikan spesies manusia dengan perkawinan selektif. Oleh karena itu bertahun-tahun genetika manusia dan eugenik melekay dalam pikiran masyarakat, tetapi sampai sekarang pengetahuan manusia tentang geetika masih sangat kurang untuk dapat menganjurkan kebijaksanaan eugenik secara tegas. Perkembangan terakhir telah banyak dibahas secara luas dalam berbagai diskusi ilmiah. Luasnya jangkauan pemasyarakatan dan kemajuan dalam bidang genetika ini disebabkan genetika merupakan suatu disiplin ilmu yang bagianbagiannya dalam banyak hal mempunyai potensi menyentuh manusia dan masyarakat secara langsung. Sumbangannya sangat terasa dalam memecahkan berbagai masalah kesehatan seperti, knker dan bayi tabung. Dengan konstitusi tersebut genetika terkendali bahkan sampai mempengaruhi evolusi manusia. Oleh karena dampak potensial studi genetika sangat besar, Anna C.Pai, menyatakan setiap orang mutlak mempunyai pemgetahuan dasar mengenai prinsip-prinsi ilmu ini. Hanya dengan cara demikianlah arti sebenarnya dan manfaat ilmu tersebut dapat diserap manusia sebagai bagian dari lingkungan alam suatu planet yang terancam punah. Oleh karena itu, ia berkesimpulan manusia secara umum haruslah diberikan pemahaman tentang dasar-dasar genetika.

\section{HASIL DAN PEMBAHASAN}

Qiyafah dalam pandangan Asy-Syafi iyah.

Salah satu metoda menetapkan nasab menurut mazhab Syafi`i adalah berdasarkan penetapan qiyafah. Qiyafah merupakan istilah metoda yang digunakan untuk perbuatan qa if, sedangkan qalif itu sendiri adalah seseorang yang dapat mengenali jejak orang lain dan sekaligus dapat mengetahui, menentapkan siapa yang punya jejak tersebut. Penetapan siapa yang punya jejak tersebut dilaksanakan qa if berdasarkan hasil penelitian dan firaatnya- dengan pendekatan melihat kemiripan, kesamaan- serta dapat pula mengetahui kenasaban seseorang berdasarkan ciri-ciri anggota tubuh orang yang diteliti. Berdasarkan deskripsi ini, dapat dipahami bahwa qa if adalah seseorang yang mempunyai keahlian, kemampuan khusus yang diberikan Allah pada dirinya berkemampuan untuk melihat dan menetapkan hubungan kenasaban seseorang dengan orang lain. Ketetapan yang diberikan qa if tersebut merujuk kepada tanda-tanda kemiripan antara seseorang dengan orang lain, yaitu antara seorang anak dengan orang tuanya. Dengan demikian maka pada hakikatnya qiyafah merupakan suatu tindakan seseorang untuk melakukan penelitian, pemeriksaan kenasaban seseorang berdasarkan kemiripan sesuai dengan ciri-ciri yang dimilki antara seorang dengan lainnya. Dan tidak dapat dimungkiri bahwa qiyafah merupakan keahlian seeorang yang telah dianugrahkan Allah kepadanya. Penjelasan ini dapat dilihat dalam literatur mazhab asy-Syafi i sebagai berikut:

1. Muhammad Khatib asy-Syarbaini; 
Hakim Siregar A : Korelasi Qifayah dan Genetika Dalam Menetapkan Nasab Perspektif Imam Syafi'i

Bermakna; "Pada pasal ini membicarakan tentang syarat-syarat qa if dan penjelasan penetapannya terhadap nasab seseorang dengan orang lainnya. Penyusun buku ini telah menyebutkan sebagian hukum qa if dalam bab `iddah dan laqit (anak terlantar). Qa if secara etimologi ialah orang yang mengikuti (meneliti) jejak orang lain. Dan secara terminologi adalah seseorang yang berkemampuan, dapat menghubungkan nasab seseorang dengan orang lainnya berdasarkan kemiripan, kesamaan yang dimiliki masing-masing orang.

2. Al-Bujairami,

Menurut al-Bujairami, kemampuan qa if untuk mengetahui hubungan nasab merupakan keahlian khusus yang diberikan Allah swt. kepada siapa saja yang ingin mempelajarinya. Oleh sebab itu, praktik qiyafah dapat dikelompokkan ke dalam salah satu cabang ilmu pengetahuan dan yang paling tepat adalah ke dalam disiplin ilmu hayat/ biollogi." Sebab, qiyafah adalah satu disiplin ilmu; dan siapa yang mengetahuinya ia akan dapat menerapkannya.

3. Ar-Ramli,

Imam ar-Ramli, mengatakan bahwa “ (Qiyafah), merupakan satu cabang dari ilmu pengetahuan, maka barang siapa yang dapat memahaminya, akan dapat melaksanakannya. Penjelasan Ramli ini semakin memperkuat kedudukan metoda qiyafah untuk dapat digunakan dalam menentukan naab seseorang dengan benar..

4. Zakariya al-Anshari..

Sebagaimana ulama yang lain, Zakaraiya al-Anshari, menegaskan bahwa praktik qa if dalam menghubungan dan menentukan nasab seseorang merupakan ilmu khusus yang dimiliki seseorang, hal ini karena Allah memberikan keahlian kepada seseorang denan anugrah-Nya. "Qa if, adalah orang yang berkemampuan menghubungkan kenasaban seseorang ketika terjadi syubhat berdasarkan keahlian yang dimilki seseorang yang diberikan Allah padanya berupa ilmu tentang itu" Dari penjelasan para ulama syafi iyah tersebut di atas dapat dipahami bahwa mazhab ini berpendapat qiyafah adalah salah satu ilmu pengetahuan yang diberikan Allah secara khusus kepada seseorang. Dari uraian ini dipahami bahwa ilmu ini terkesan bersifat spiritual yang datangnya dari Allah kepada orang yang dikehendaki-Nya. Namun demikian, berdasarkan keterangan lain dalam pandangan mazhab Syafiiyah bahwa ilmu ini kendatipun dipandang bersifat spiritual, namun dapat dapat dipelajari dan dapat juga dipraktikan oleh siapa saja yang mmenguasai ilmu ini dengan baik dan benar." Qiyafah adalah ilmu yang membicarakan tentang cara mendapatkan bukti (Istidalal) dari sisi postur tubuh dua orang yang ada kesamaannya atau kemiripan dari sifat-sifat mereka untuk menentukan asal kenasaban, keturunan mereka." "Qitafah, merupakan suatu ilmu yang membahas cara membuktikan (istidlal) melihat dari sisi postur tubuh seseorang untuk mengetahui kesamaan sifat-sifat menghubungkan kenasaban, keturunan antara dua orang (yang diragukan kenasabannya)."

Dari dua ungkapan ini oleh Mustafa bin Abdullah al-Qastantini ar-Rumu al-Hanafy, dan Sidiq bi Hasan, keduanya mengakui bahwa qiyafah sebagai salah satu metodologi ilmu untuk dapat dijadikan landasar meneliti hubungan kenasaban seseorang dengan oarng lainna, bila diragukan atau untuk menetapkan hubungan kenasaban mereka. Unsur yang menjadi objek penelitian dapat melihat dari sisi postur tubuh, sifat-sifat lainnya dan sampai pada akhlaknya. 
Hakim Siregar A : Korelasi Qifayah dan Genetika Dalam Menetapkan Nasab Perspektif Imam Syafi'i

\section{DAFTAR PUSTAKA}

Ar-Ramli, Nihayah Al-Muhtaj, zuz IV, tt,Dar al-Kutub Bairut.

Ahmad Warson Munawir, Al-Munawir, 1984, Pondok Psantren Al-Munawir Yogyakarta.

Ahmad A.K Muda, Kamus Lengkap Kedokteran, 2003, Genetika Press Bandung.

Alan E.H.Emery, Dasar-dasar Genetika Kedokteran,(terj) Sumiati Ahmad, 2003, Yayasan Essentia Medica Yogyakarta.

Al-Bujairami, Hayiah al-Bujairami, zuz JV, tt, Dar al-Fikri, Kairo.

Anna C.Pai, Dasar-dasar Genetika , (terj) Muchidin, 1992, Erlangga Jakarta.

Lahmudin Nasution, Qawl Qadim dan Qawi Jadid Muhammad Ibn Idris al-Syafi $i$, Suatu Studi tentang Dinamika Hukum Dalam Mazhab al-Syafi i dan Relevanzinya dengan Pembaharuan Hukum Islam.1998, IAIN Syarif Hidayatullah Jakarta.

Muhammad Khatib Sarbaini, Mughni al-Muhtaj, IV, 1971, Dar Al-Fikri, Kairo.

Ma`ruf Luis, Kamus Al-Munjid, tt , al-Masyriq Bairut.

Mahyuddin Abd.Salam, Pola Pikir Imam Syafi i (terj) Mhd.Mahrus Muslim,1995, Fikahati Aneska, Jakarta.

Mustafa bin Abdullah al-Qastantini, Kasyfu Azzunun, 1992, Dar al-Kutub Ilmiah Bairut.

Suryo, Genetika Manusia, 2003, University Press Gajah Mada Yogyakarta.

Sidiq Al-Hasan, al-Qunuji, Abjad al-Um, Dar al-Kutub Ilmiah Bairut.

Wahbah Zuhaili, Fiqh al-Islami Wa Adillatuh, 1990, Dr.al-Fikri Bairut.

Wildan Yatim, Genetika, 1991, Tarsito Bandung.

WJS.Poerwadarminta, Kamus Umum Bahasa Indonesia, 1986, Balai Pustaka Jakarta.

Zakaria al-Anshari, Fath al-Wahhab, 1418 H, Dar al-Kutub Ilmiah, Bairut

Zamakhsyari, Ru`us Masa il, 1990, Dar Basya`ir al-Islamiah, Bairut 